\title{
Ozone analysis over the Kingdom of Saudi Arabia
}

\author{
A. K AL-Khalaf \\ Department of Meteorology, Faculty of Meteorology, Environment, \\ and Arid Land Agriculture, King Abdulaziz University, Jeddah, Saudi \\ Arabia.
}

\begin{abstract}
Monthly, seasonal and annual values of the total column ozone amount have been analyzed at each station of Kingdom of Saudi Arabia for the period from 1979 to 2006 . It is found that ozone variation is function of latitude, where the higher values of ozone occurs at the northern stations, it decreases gradually from north to south. The values of ozone start to increase gradually from november to reach its maximum at march then it decreases gradually to reach its minimum at october. There is no persistance in the season of higher ozone values, where the season of higher values is differ with different latitudes. Study of the horizontal distribution of the monthly average of ozone for each month of the year has been made. It is found that the largest column amounts occurs north of $r^{\circ} \mathrm{ON}$ during winter and spring months and coincide with a lowering of the tropopause. Latitudinal gradients in column ozone are very strong in winter and spring months specially north of latitude $20 \mathrm{oN}$. The strong latitudinal gradient of ozone with the increase of its quantity over the north of KSA in winter and spring is due to midlatitude traveling depressions from west to east that affect the weather in this period. The climatological distribution of ozone throughout the months of the year reflect the effect of meteorological factors and pressure system affecting in weather and climate of our area.
\end{abstract}

\section{Introduction}

Ozone is capable of absorbing wavelengths (ultraviolet radiation) of biologically damaging ultraviolet light. This radiation has been linked to health and environmental concerns. Most of this ozone (90 percent) is found in the stratosphere, the layer of the atmosphere lying between the altitudes of 10 and 50 kilometers (Kowalok 1993). Heat generated from this absorption causes the 
temperature to increase with altitude in the stratosphere. The resulting temperature profile is largely responsible for the dynamic stability of the stratosphere (Shen et al. 1995). Hence, the presence of the stratospheric ozone layer is vital both to human health and to the dynamic stability of the stratosphere.

Stratospheric circulation plays an essential role in determining the spatial and temporal distribution of ozone. Ozone circulation can be illustrated through the Brewer-Dobson circulation model (Figure 1). It consists of a meridional circulation in each hemisphere, with air rising into the stratosphere in the tropics (where there is little seasonal variation in ozone), moving poleward, with descent and entrainment into the troposphere at high latitudes. This mass circulation transfers ozone from the tropical production regions and allows accumulation near the poles, accounting for the spring polar maximum (Shen et al. 1995). The objective of this paper is concerned with the analysis of monthly seasonal and annual ozone values over the Kingdom of Saudi Arabia (KSA). 


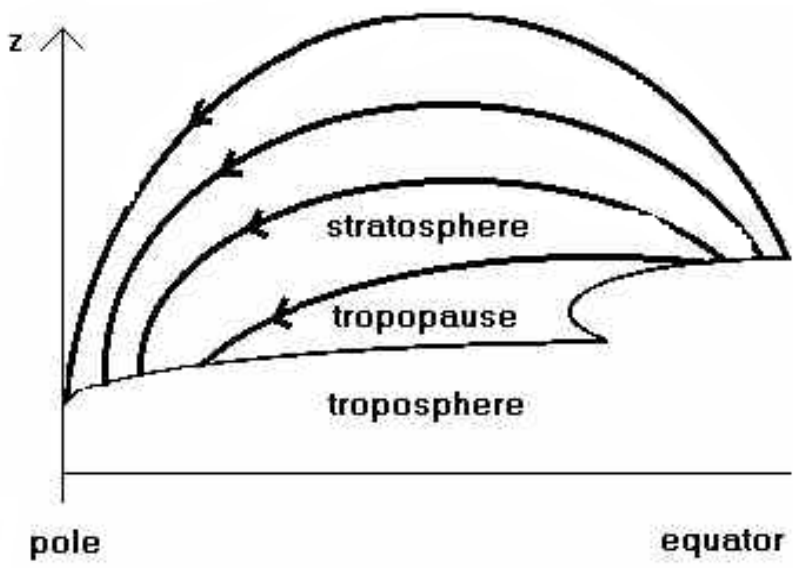

Figure 1: Schematic illustration of the Brewer Dobson circulation, proposed to account for the observed distribution of various conserved trace constituents in the lower stratosphere (James 1994). Arrows indicate direction of transport.

\section{Data and methodology}

Total Ozone Mapping Spectrometer (TOMS) aboard Nimbus-7 and Meteor-3 provided global measurements of total column ozone on a daily basis and together provide a complete data set of daily ozone from November 1978 - December 1994. After an eighteen month period when the program had no on-orbit capability, ADEOS TOMS was launched on August 17, 1996 and provided data until June 29, 1997. Earth Probe TOMS was launched on July 2, 1996 to provide supplemental measurements, but was boosted to a higher orbit to replace the failed ADEOS. Earth Probe continues to provide near realtime data. . Data resolution is $1^{\circ}$ latitude by $1.25^{\circ}$ longitude. The data are measured in Dobson Unit (DU) where 1000 DU are equivalent to $1 \mathrm{~cm}$ of ozone at $1000 \mathrm{hPa}$. The data set used in this study encompassed the period from 1979 to 2006. Occasionally, there are 
missing data (about $1 \%$ of the total data) which need to be dealt with in some fashion for calculation of the climatology. Linear interpolation is used to estimate missing values in order to make the time series complete, which enables a computation of monthly and yearly means and a time series analysis of the daily data. Monthly and yearly means are calculated based on these daily values, assuming that they are representative of daily means.

The used data were obtained from the Total Ozone Mapping Spectrometer (TOMS) Ozone processing team NASA/GSFC code 613.3 from the website http://toms.gsfc.nasa.gov/ozone/ozonev8.html. The stations under study are distributed all over KSA, although their spatial density is low and uneven over some parts of the country. Table 1 and figure 2 illustrate the name, the position and the elevation of each of KSA meteorological stations.

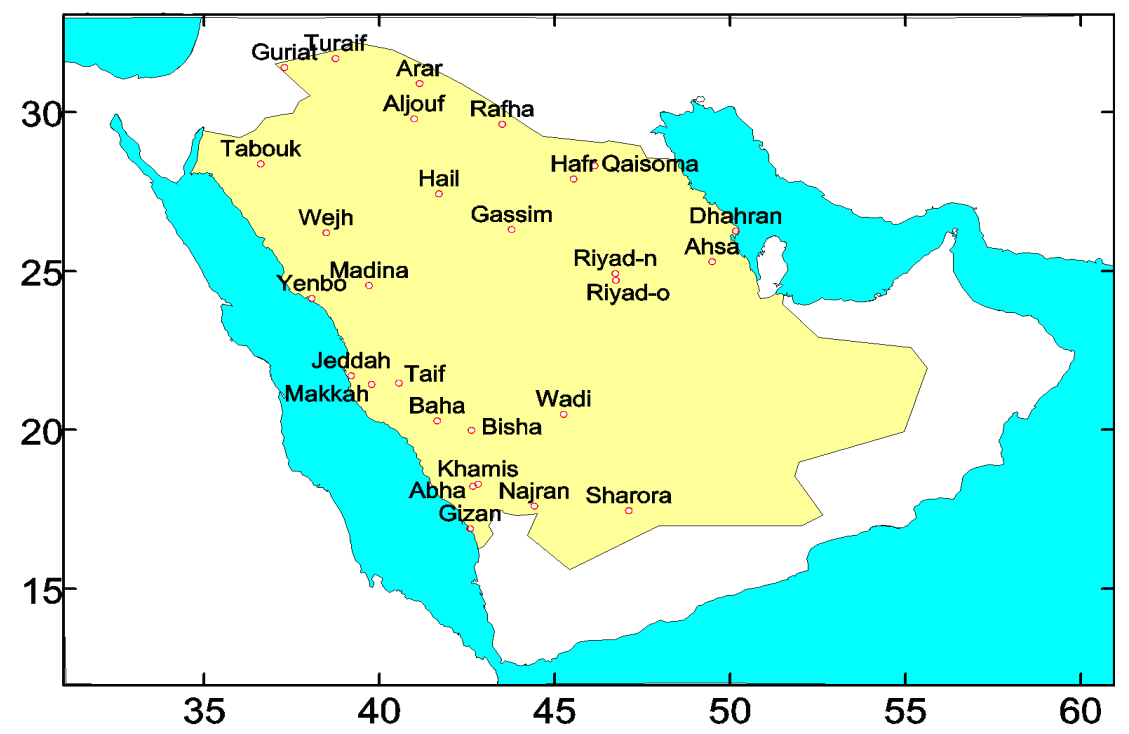

Fig. 2: The name and position of KSA stations. 
Table 1: The name, position and elevation of KSA stations.

\begin{tabular}{|c|c|c|c||c|c|c|c|}
\hline Name & Lat $^{\circ}$ & $\begin{array}{c}\text { Long } \\
{ }^{\prime}\end{array}$ & Elevation(m) & Name & Lat $^{\circ}$ & $\begin{array}{c}\text { Long }^{\circ} \\
\text { Elevation(m) }\end{array}$ \\
\hline TURAIF & 31.68 & 38.73 & 852.44 & $\begin{array}{c}\text { WADI } \\
\text { ALDWASER }\end{array}$ & 20.50 & 45.25 & 635.60 \\
\hline GURAIT & 31.40 & 37.28 & 503.90 & SULAYEL & 20.46 & 45.617 & 10.40 \\
\hline ARAR & 30.90 & 41.14 & 548.88 & MADINA & 24.54 & 39.69 & 3.58 \\
\hline ALJOUF & 29.78 & 40.98 & 668.74 & YENBO & 24.14 & 38.06 & 1452.75 \\
\hline TABOUK & 28.37 & 36.60 & 444.10 & JEDDAH & 21.71 & 39.18 & 240.35 \\
\hline HAIL & 27.43 & 41.69 & 768.11 & MAKKAH & 21.43 & 39.79 & 701.02 \\
\hline WEJH & 26.20 & 38.47 & 357.60 & TAIF & 21.48 & 40.55 & 614.39 \\
\hline RAFHA & 29.62 & 43.49 & 413.00 & BAHA & 20.29 & 41.64 & 1651.88 \\
\hline ALQUSOMA & 28.31 & 46.13 & 1001.52 & BISHA & 19.99 & 42.61 & 1161.97 \\
\hline HAFRBATEN & 27.90 & 45.53 & 646.71 & ABHA & 18.23 & 42.66 & 2055.93 \\
\hline DHAHRAN & 26.25 & 50.16 & 16.77 & KHAMIS & 18.29 & 42.80 & 2093.35 \\
\hline AHSA & 25.29 & 49.48 & 23.73 & MUSH & 17.61 & 44.41 & 1212.33 \\
\hline GASSIM & 26.30 & 43.76 & 178.17 & SHARURA & 17.46 & 47.10 & 724.65 \\
\hline $\begin{array}{c}\text { RIYADH } \\
\text { NEW }\end{array}$ & 24.92 & 46.72 & 613.55 & GIZAN & 16.90 & 42.58 & 7.24 \\
\hline RYDOLD RY & 24.71 & 46.73 & 619.63 & \multicolumn{7}{|c|}{} & & & & \\
\hline
\end{tabular}

\section{Results and Discussion}

\subsection{Monthly analysis}

In this section, I will discuss the behaviour of the monthly values of ozone of KSA stations during the period from 1979 to 2006 . Figure 3 shows the monthly values of ozone for the selected 16 stations. The illustrated stations were arranged from north to south. Results of the analysis of the monthly time series for different stations show that an annual wave is the domaniant wave at all stations, and the amplitude of this wave at the northern stations is greater than those in the southern stations. The higher values of ozone occur at the northern stations, it decreases gradually from north to south. This can be seen by comparing the time series of Turaif with the corresponding time series of Sharorah. The values of the northern time series ranged from 
260 DU to 320 DU, while for the southern stations it ranged from 240 DU to 280 DU. The maximum measured value over KSA stations occurs at Turaif (359 DU) in the year 1982, while the minimum value occurs at Alahsa and Riyadh old (185 DU) in the year 1993. A relatively large minimum value of ozone at all stations occurs at the year 1993. This minimum follows the June 15, 1991 eruption of Mt. Pinatubo and is caused mainly by the chemical and/or dynamical effects of this aerosol injection event (Hadjinicolaou et al., 1997; Stenchikov et al., 2002; Rozanov et al., 2002). Negative trends is the persistance feature occurs at all stations.

At northern midlatitudes in winter and spring, it is well known that both poleward and equatorward synoptic-scale wave breaking events occur in the lower stratosphere (e.g., Nakamura, 1994; Peters and Waugh, 1996). In the northern hemisphere, anticyclonic poleward wave events are characterized by northward deformations of the subtropical tropopause resulting in protrusions of ozone-poor, low potential vorticity (PV) air that extend from the tropical upper troposphere into the midlatitude lowermost stratosphere (cf. Holton et al., 1995). These poleward events are often complemented by equatorward wave events at other longitudes that generate tongues of ozone-rich stratospheric air extending into the tropical upper troposphere (Waugh et al., 2000). The resulting meandering boundary between low ozone regions and higher ozone regions at northern midlatitudes has been referred to as the "subtropical front" by Hudson et al. (2003). 
In this section, the average value (1979- 2006) of ozone of each month of the year for the KSA stations also will be displayed. The displayed results arranged from the northern stations to the southern stations as shown in figure 4. Figure $4 \mathrm{a}$ illustrates the average monthly values of ozone of each month of the year for the stations Arar, Turaif, Guriat, Aljouf and Tabouk. It is clear that the maximum values of ozone at each station appear at the months of the spring season followed by the months of winter season. The minimum values of ozone appear at the months september, october and november. It can be seen that the values of ozone start to increase gradually from november to reach its maximum at march then it decrease gradually to reach its minimum at october. Also it is interesting to note that the values of ozone are function of latitude. This can be seen from the values of ozone of the different stations at each month. Although the five stations exist in the north of KSA and in the same area with small difference in latitude the values of ozone decrease from the north one (Turaif; its latitude is $31.68^{\circ} \mathrm{N}$ ) to the southern one (Tabouk; its latitude is $28.37^{\circ} \mathrm{N}$ ). Figure $4 \mathrm{~b}$ shows the average monthly values of ozone for each month of the year for the stations Hail, Alwajh, Rafha, Alqaisoma and Hafr Albaten. 

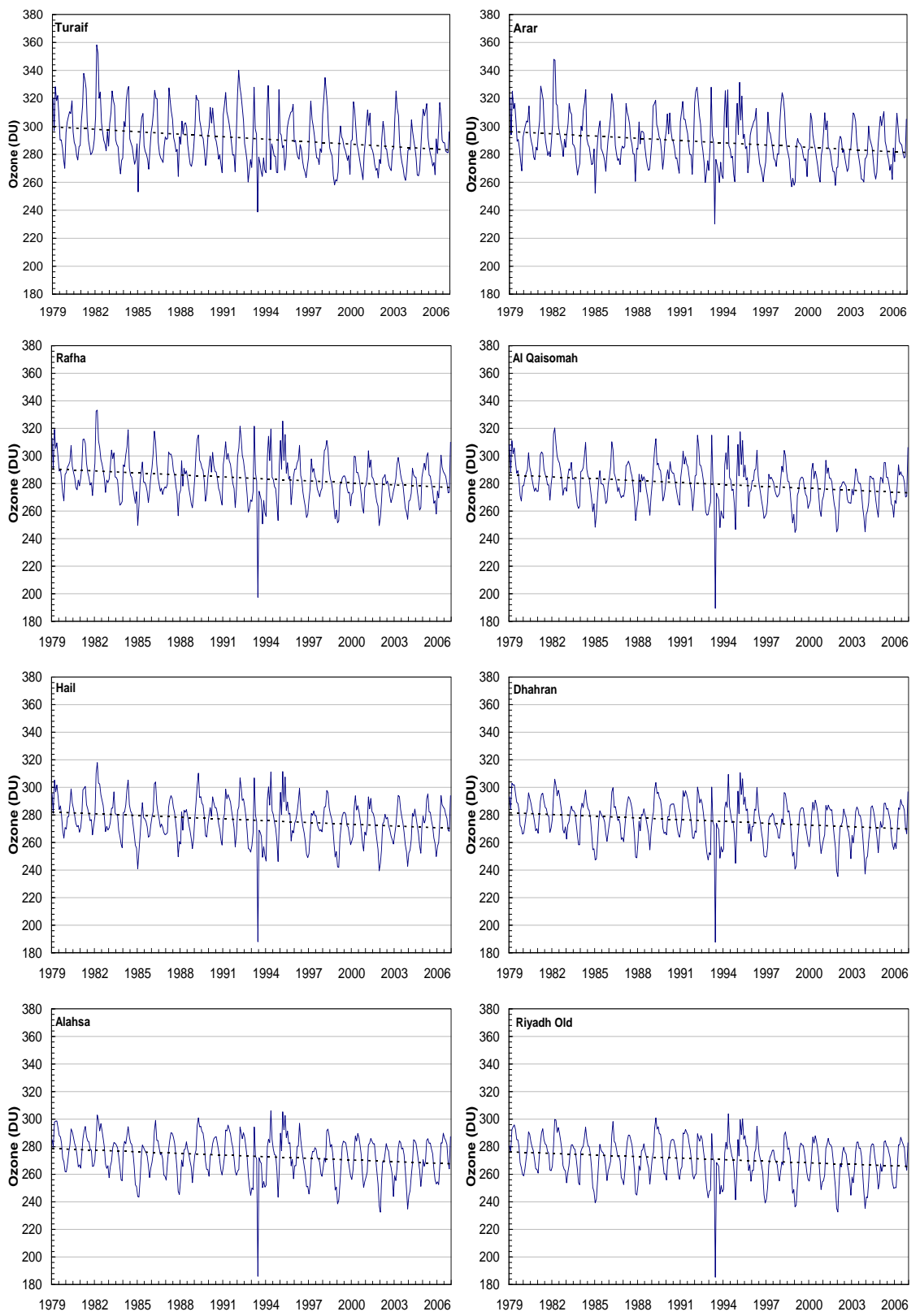

Fig. 3a: The monthly values of ozone for the stations Turaif, Arar, Rafha, Alqaisoma, Hail, Dhahran, Alahsa, Riyadh Old during the period from 1979 to 2006. 

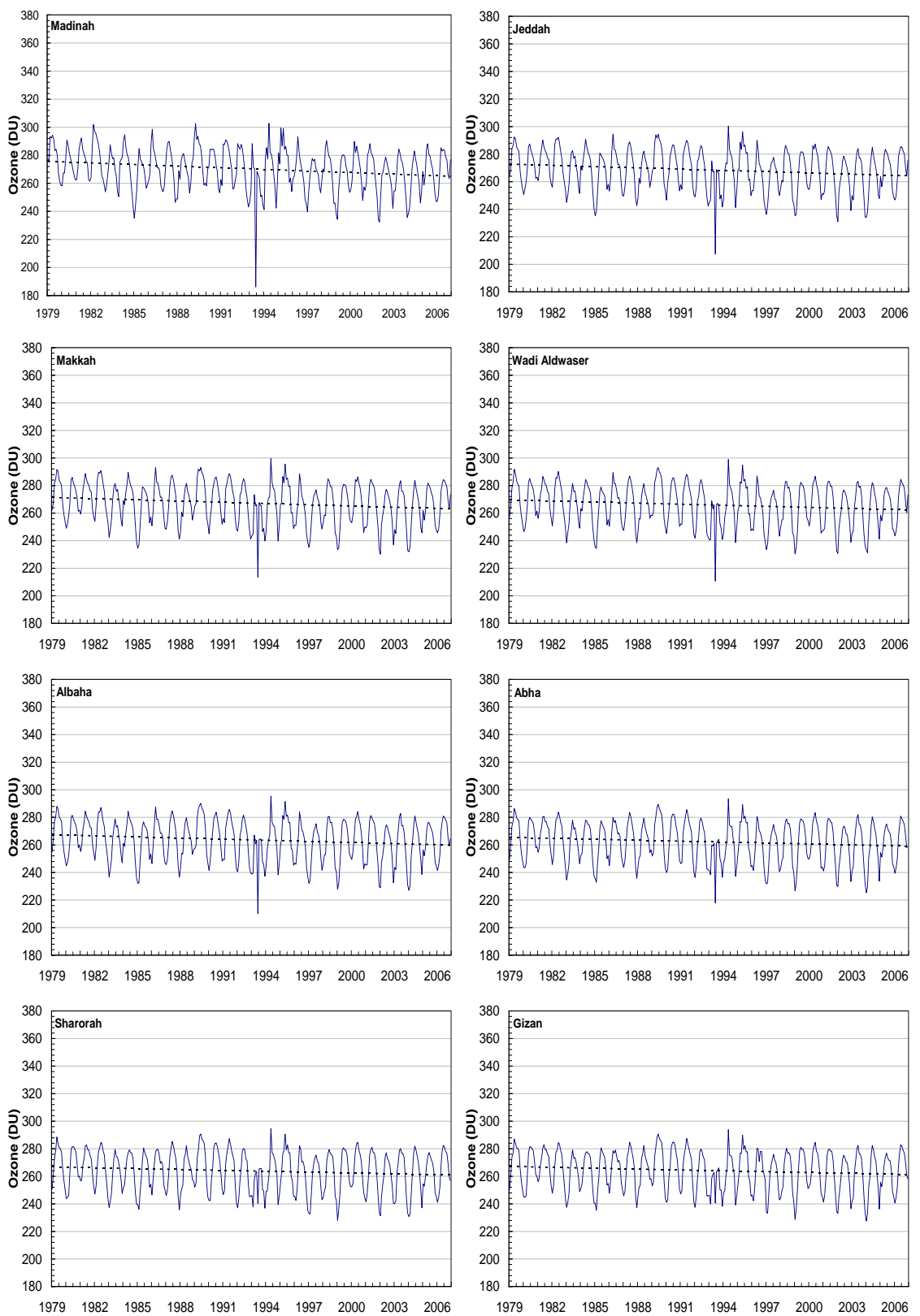

Fig. 3b: As in Fig. 3a but for the stations Madinah, Jeddah, Makkah, Wadi Aldwaser, Albaha, Abha, Sharorah and Gizan. 
As in figure $4 \mathrm{a}$ we found that the maximum values appears in the spring months and the minimum values appears in the autumn months. Also, the values of ozone is a function of latitude, where it can be seen that the higher values throughout the months of the year occur at Rafha $\left(29.62^{\circ} \mathrm{N}\right)$ while the lowest values occurs at Alwajh $\left(26.20^{\circ} \mathrm{N}\right)$. generally, the values of ozone at these stations are lowest by $10-20 \mathrm{DU}$ from those in figure $4 \mathrm{a}$.

Figure $4 \mathrm{c}$ shows the average monthly values of ozone for each month of the year for the stations Dhahran, Alahsa, Qassim, Riyadh New and Riyadh Old. It is clear that the behaviour (pattern) of ozone at these stations is differ from those in figures $4 \mathrm{a}$ and $4 \mathrm{~b}$, where the lowest values appear at winter months and the highest values appear at spring and summer months. The difference between the average values of some months at these stations and the northern stations reaches to $30 \mathrm{DU}$. As in figures $4 \mathrm{a}$ and $4 \mathrm{~b}$ the maximum values of these stations occur in May while the lowest values occurs in november. Figure $4 \mathrm{~d}$ shows the average monthly values of ozone for each month of the year for the stations Wadi Aldwaser, Sulayel, Madinah, Yanbo, Jeddah and Makkah. The lowest values appear in winter months and november while the highest values appear at the months from March to October with maximum one at May. The difference between the average values of ozone at these stations in the most months and the northern stations exceeds 30 DU. Except Taif, the stations appear in figures $4 \mathrm{e}$ and $4 \mathrm{f}$ represent the southwest part of KSA. The lowest average monthly values occur in winter months 
while the higher average monthly values occur during the months from April to september.

\subsection{Seasonal and annual analysis}

Figures $5 \mathrm{a}, \mathrm{b}$ display the average of the seasonal ozone values at each station. Figure 5a illustrates that, the maximum values of ozone of the stations Arar, Turaif, Guriat, Aljouf and Tabouk occur in spring season (March, April, may) while the lowest values of ozone occur in autumn (September, October and November). The second maximum values occur in winter (December, January and February). The seasonal values of these stations are function of its latitude where the maximum station at spring is of Guriat (314 DU). The range of the seasonal change amounts to $36,35,40,32$ and 28 DU at Arar, 

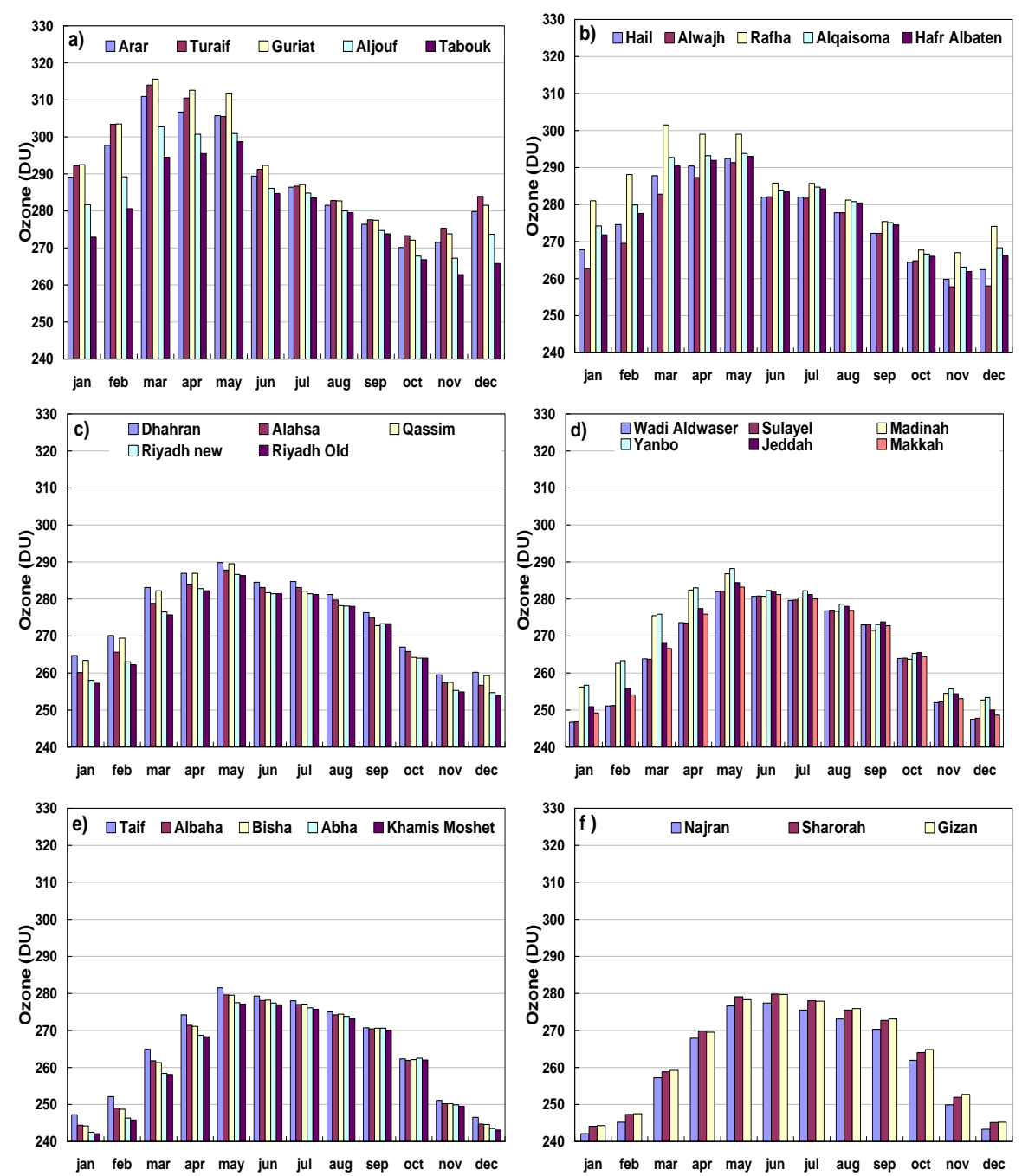

Fig. 4: The average of the monthly values of ozone for KSA stations

Turaif, Guriat, Aljouf and Tabouk respectively. Figure 5b displays the average of the seasonal ozone of the stations Hail, Alwajh, Rafha, Alqaisoma and Hafr Albaten. Also, as in Figure 5a the higher values of ozone occur at spring and the lower values occur at autumn. The difference between the two figures (Figure $5 \mathrm{a}$ and $5 \mathrm{~b}$ ) is that the 
summer values are larger than those corossponding in winter. The range of the seasonal change amounts are 26, 22, 30, 26 and $25 \mathrm{DU}$ at Hail, Alwajh, Rafha, Alqaisoma and Hafr Albaten respectively. It is clear that the seasonal values of the stations decrease with it latitudinal location. Figure 5c displays the seasonal values of ozone for the stations Dhahran, Alahsa, Qassim, Riyadh New and Riyadh Old. The behaviour of the seasonal values of these stations is differ from that in Figures $5 \mathrm{a}$ and $5 \mathrm{~b}$ where the seasonal values of spring is nearly equal those corospnnding in summer and the values of winter are the lowest values. The range of the seasonal change amounts are 20, 23, 22, 23 and 24 DU at Dhahran, Alahsa, Qassim, Riyadh New and Riyadh Old respectively.

Figure $5 \mathrm{~d}$ shows the seasonal values of ozone for the stations Wadi Aldwaser, Sulayel, Madinah, Yanbo, Jeddah and Makkah. The lowest values of these stations appear in winter while the higher values appear in summer except for Madinah and Yanbo. The difference between the average values of these stations and those in figure $5 \mathrm{a}$ is nearly 35, 30, 5, and 7 in winter spring, summer and autumn respectively. Figure 5e displays the seasonal values of ozone for the stations Taif, Albaha, Bisha, Abha and Khamis Moshet, While Figure 5f displays the seasonal values of ozone for the stations Najran, Sharorah and Gizan. These stations represent the south west area of KSA. Generally, the higher values of these stations occur in summer while the minimum seasonal values occur in winter.

Figures $6 \mathrm{a}$ and $6 \mathrm{~b}$ display the seasonal and annual analysis of ozone for 16 of KSA stations. The results of the analysis of the 
seasonal and annual time series of interest stations indicate a decreasing in ozone values gradually from northern station (Arar) to southern station (Gizan), which means that, it decreases with decreasing latitudes. There is no persistance in the season of higher ozone values, where the season of higher values is differ with different latitudes, these results can be illustrated in table 2. The conclusion from Figure 6 is that, the variability of ozone in the low- latitude is acceptabley small at a few DU, where as it becomes large values when extending outside the tropics..

The seasonal variation reveals a nearly perfect sine wave with the maximum values in spring and minimum values in autumn (figure 6a). Seasonal variation of ozone may be decomposed into two parts, a photochemical and a dynamic (Aesawy et al., 1994). Since both the production and destruction of ozone depend on solar radiation, therefore the photochemical component is a function of solar intensity. Ozone is produced mainly in the tropics and exported to higher latitudes by the atmospheric circulation which plays an important role for local ozone at higher latitudes. As the maximum and the minimum occur in April-October when solar radiation is about the same, the atmospheric transport must have played a more active role in forming the seasonal pattern.

The behaviour of the annual time series of each station during the period of study reveals a nearly perfect sine wave with the maximum values in 1982, 1992 and 1995 at the northern stations and a minimum values in 1985, 1993 and 2000. at the middle stations, the maximum annual values appears in the years 1982, 1989 and 1995 while the 
minimum values appears in 1985, 1993 and 2002. At the southern stations the maximum annual values appears in 1981, 1989 and 1995 while the minimum occurs at 1983 and 1997.

Table 2: The arrange of higher ozone season with latitudes.

\begin{tabular}{|c|c|c|}
\hline Stations & Latitude & Seasons \\
\hline ARAR - GURAIT - TURAIF & $31.68-30.90$ & $\begin{array}{c}\text { Spring - Winter - } \\
\text { Summer - Autumn }\end{array}$ \\
\hline $\begin{array}{c}\text { ALJOUF - RAFA - TABOUK - } \\
\text { ALQUSOMAH - } \\
\text { HAFRBATEN- HAIL - WEJH - }\end{array}$ & $29.78-27.90$ & $\begin{array}{c}\text { Spring - Summer - } \\
\text { Winter - Autumn }\end{array}$ \\
\hline $\begin{array}{c}\text { DHAHRAN - GASSIM - } \\
\text { NA - MADINA - RIYADH } \\
\text { NEW - RYDOLD old - } \\
\text { YENBO }\end{array}$ & $26.30-24.14$ & $\begin{array}{c}\text { Spring - Summer - } \\
\text { Autumn - Winter }\end{array}$ \\
\hline $\begin{array}{c}\text { JEDDAH - MAKKAH - TAIF - } \\
\text { BAHA - WADI AWASER - } \\
\text { SULAYER - BISHA - ABHA - } \\
\text { KHAMIS MUSH - NAJRAN - } \\
\text { SHARURA - GIZAN }\end{array}$ & $21.71-16.90$ & $\begin{array}{c}\text { Summer - Spring - } \\
\text { Autumn -Winter }\end{array}$ \\
\hline
\end{tabular}



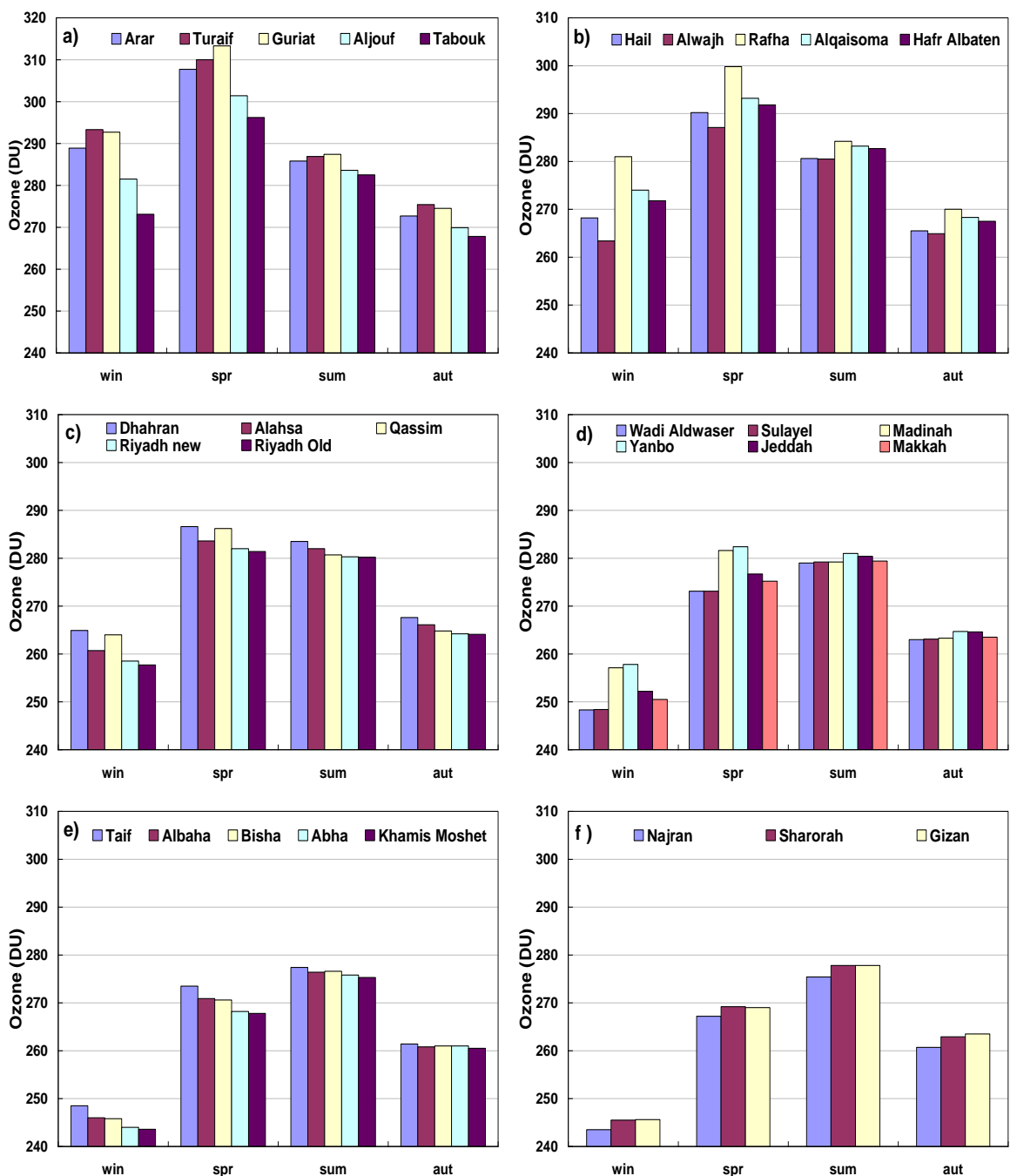

Fig. 5: The average of the seasonal values of ozone for the KSA stations. 

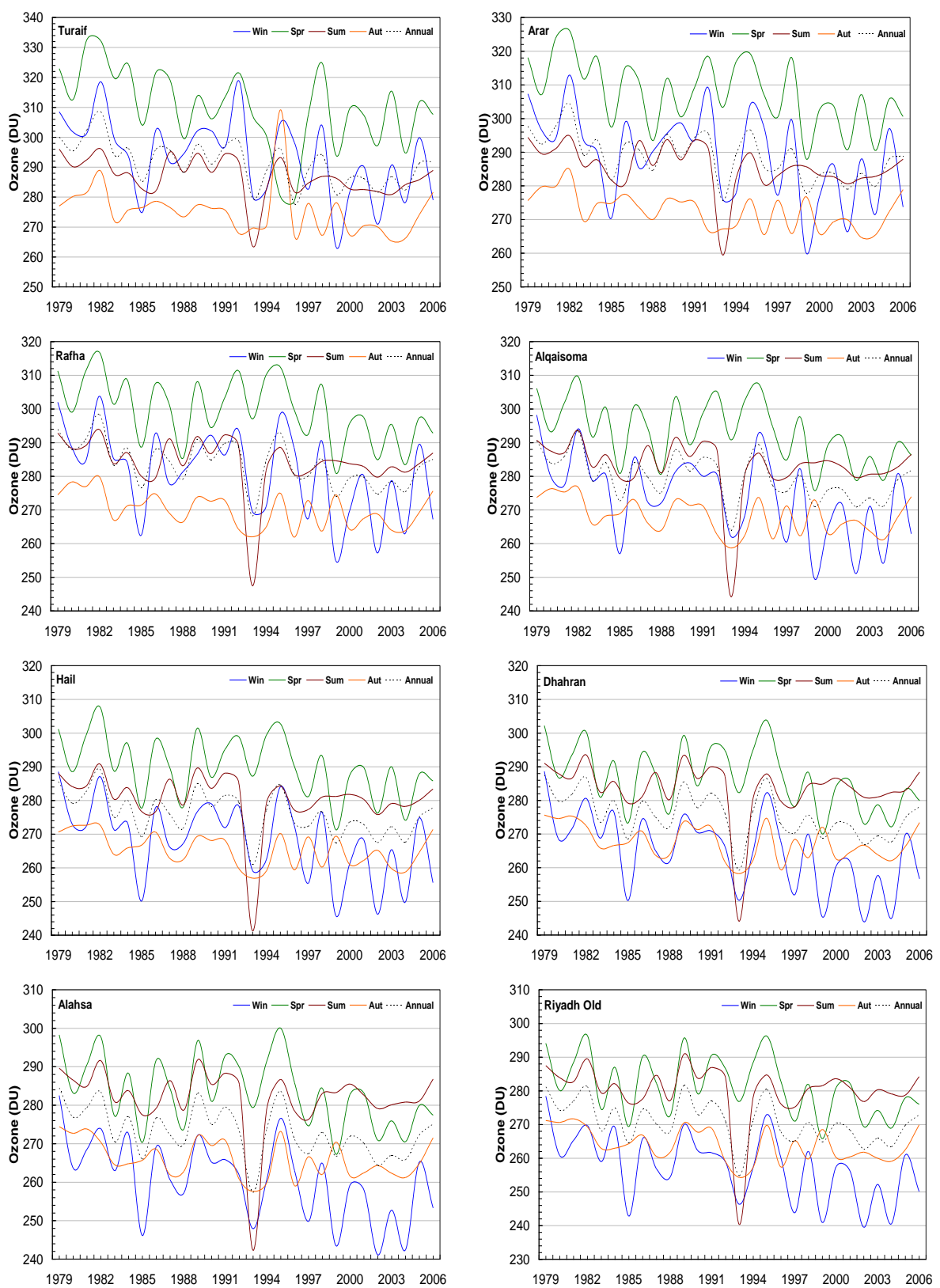

Fig. 6a: The annual and seasonal values of ozone for the stations Turaif , Arar, Rafha, AlQaisomah, Hail, Dhahran, Alahsa and Riyadh old for the period from 1979 to 2006. 

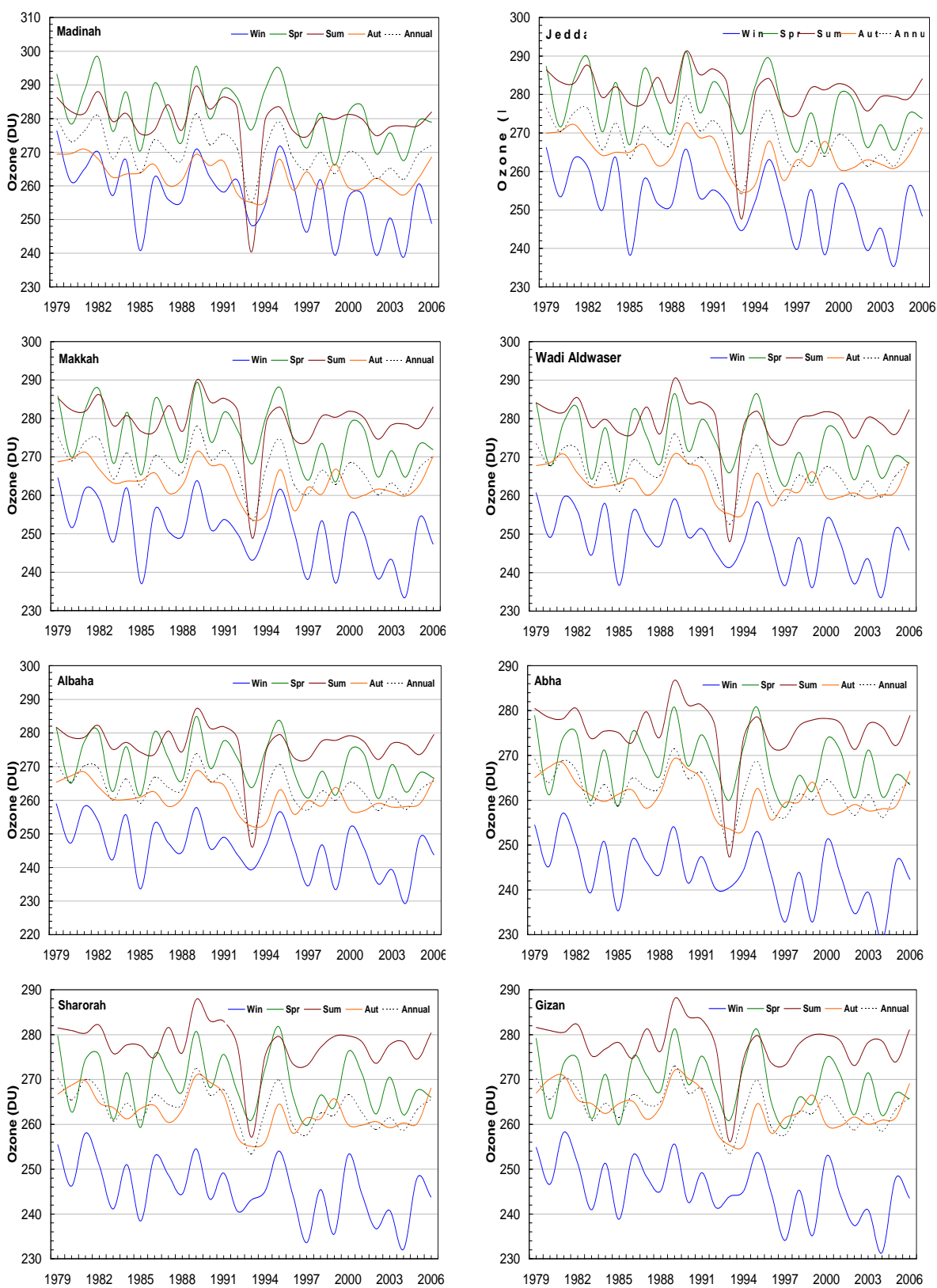

Fig. 6b: The annual and seasonal values of ozone for the stations Madinah, Jeddah, Makkah, Wadi Aldwaser, Albaha, Abha, Sharorah and Gizan for the period from 1979 to 2006. 


\subsection{Monthly horizontal distribution of total ozone}

Figures 7 and 8 show the horizontal distribution of the monthly average of ozone (1979 - 2006) for each month of the year. These figures depect monthly variability of total column ozone over KSA based on all available data from 1979 to 2006. Because most ozone lies in the stratosphere, stratospheric column ozone and total column ozone exhibit similar seasonal cycles and latitudinal variability. The largest column amounts occur north of $30^{\circ} \mathrm{N}$ during winter- spring months and coincide with a lowering of the tropopause. Generally, ozone is seen to decrease with latitude, where Latitudinal gradients in column ozone are very strong in winter and spring months specially north of latitude $20^{\circ} \mathrm{N}$. and are $\approx 3-4$ times larger than in summer and autumn seasons. Despite the differences in latitudinal gradient in ozone south of $20^{\circ} \mathrm{N}$, ozone values show the smallest amounts in winter and spring months. With the beginning of May the values of ozone increase gradually from south to north where its value in the middle and south of KSA is greater than the previous months. This situation exists also in June. The lowest values of ozone in winter and spring months occurs at the south specially at the south west of KSA. The difference between the values of ozone at north and south of KSA reachs to about 50 DU in winter and about 35 DU in spring. The climatological distribution of ozone throughout the months of the year reflect the effect of meteorological factors and pressure system affecting in weather and climate of our area. The 
strong latitudinal gradient of ozone with the increasing of its quantity over the north of KSA in winter and spring is due to midlatitude traveling depressions from west to east that affect the weather in this period. The effect of Red Sea and Red Sea trough can be detected from the distribution of ozone over the Red Sea throughout the months of the year.

The existence of a link between meteorological features on the synoptic scale and ozone column totals was estiblished by Dobson and co-workers from the 1920s onward (Dobson and Harrison 1926; Dobson 1930; Dobson et al. 1929, 1946). They found that total ozone increases and decreases with the passage of cold and warm fronts respectively, and that high total ozone is found to the rear of developing surface cyclones and near the center of mature ones. Correspondingly, low total ozone 
a) ozone December

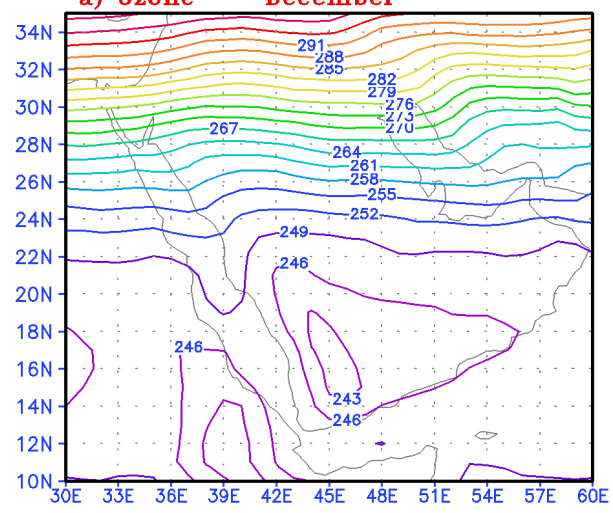

c) ozone February

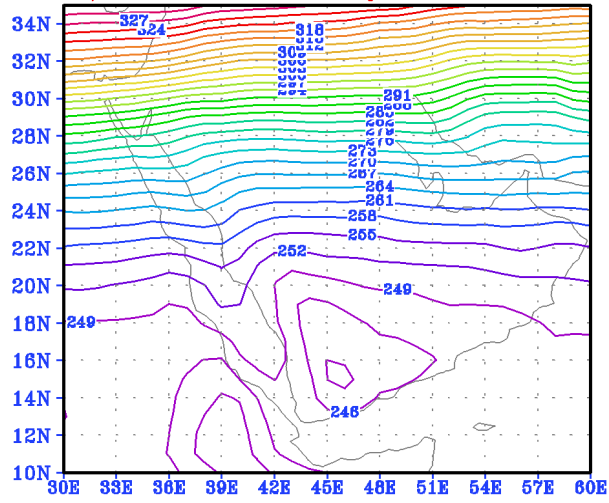

e) ozone April

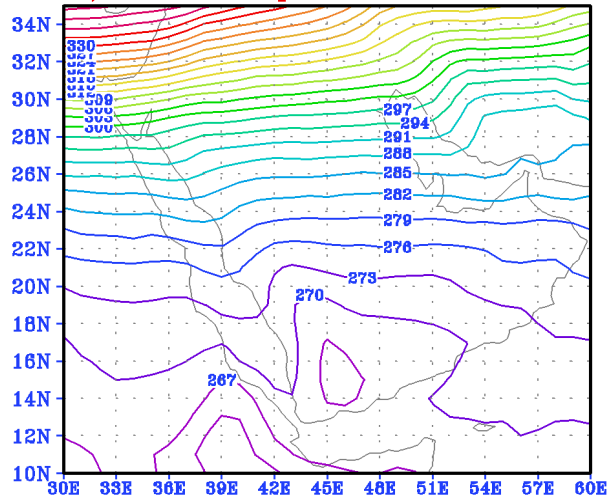

b) ozone January

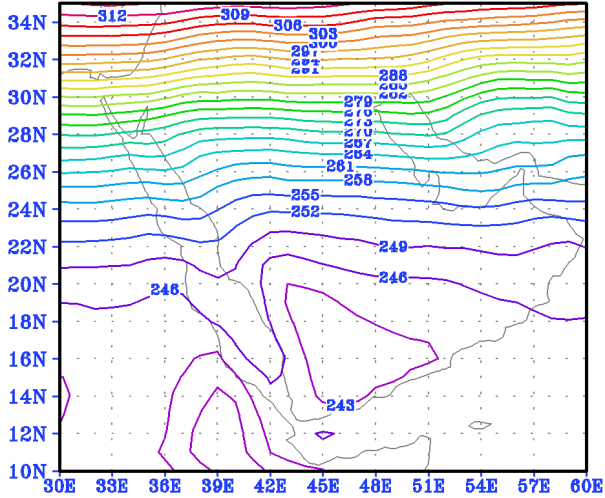

d) ozone March

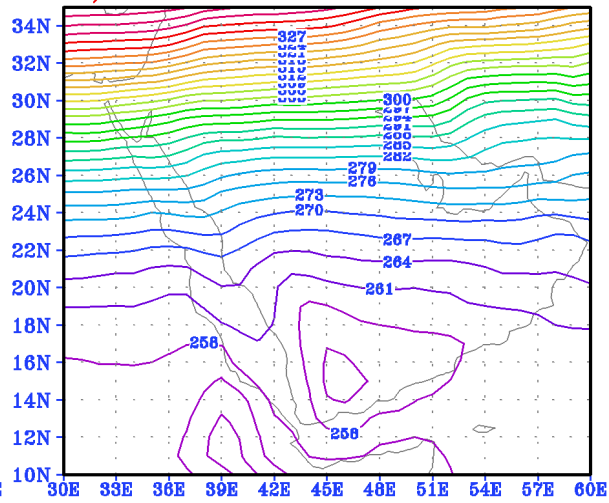

f) ozone May

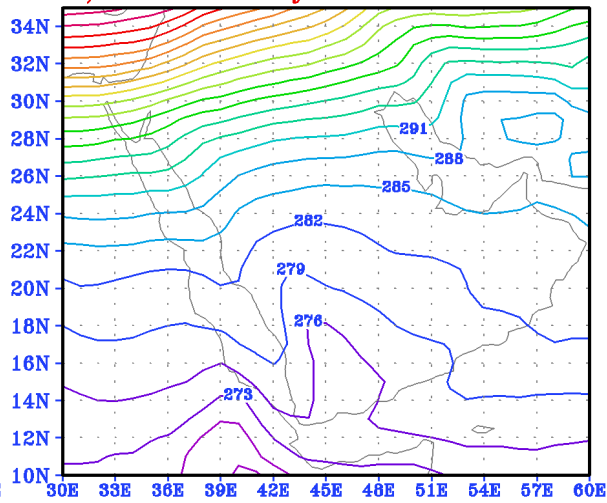

Fig. 7: The horizontal distribution of the monthly average values of ozone (1979-2006) for the months December, January, February, March, April and May. 
a) ozone June
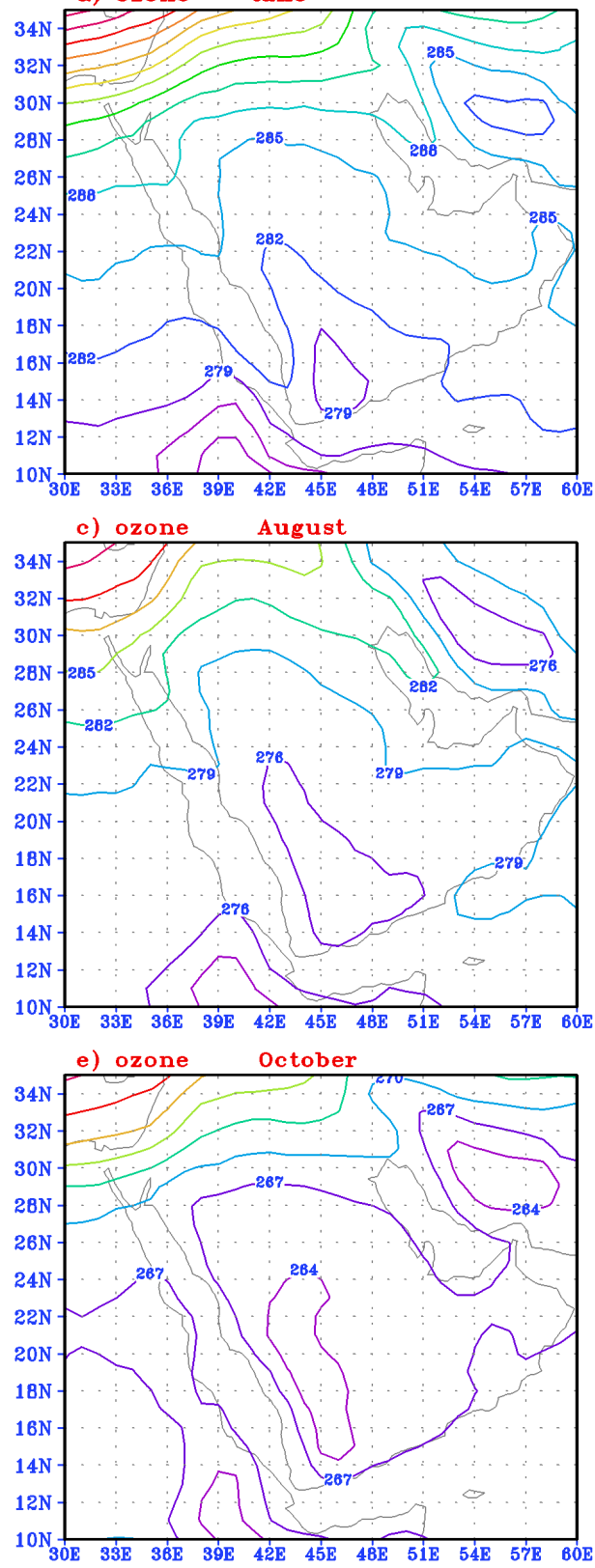

b) ozone July

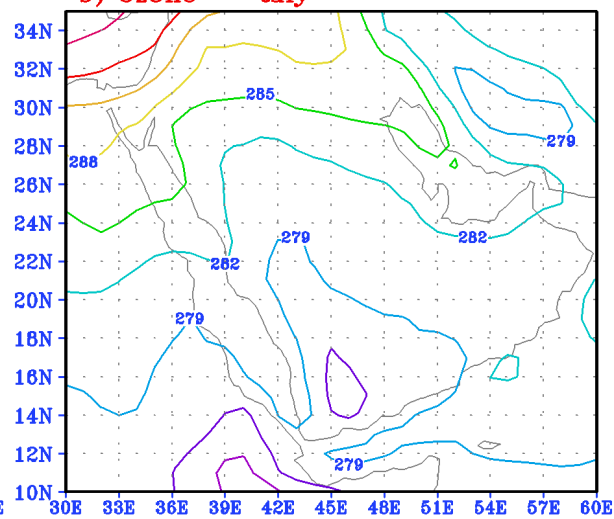

d) ozone Septemper
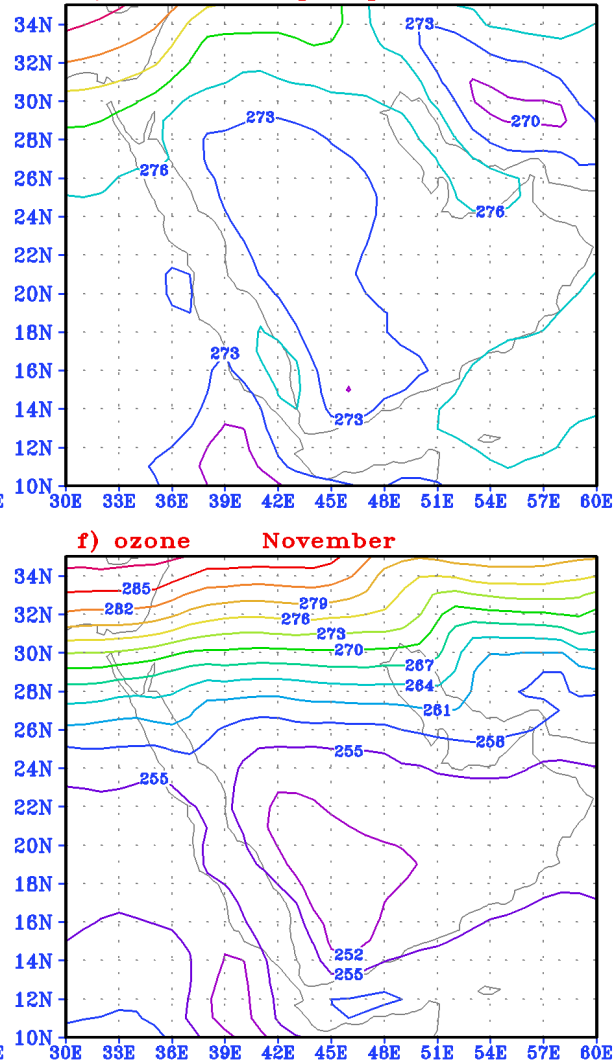

Fig. 8: As in Fig. 7 but for the months June, July, August, September, October and November. 
accompanies surface anticyclones. These correlations occur because synoptic weather systems perturb the flow above as well as below the tropopause, and vertical-motion fileds in the lower stratosphere associated with trough/ridge pattern were shown by reed (1950) to be capable of producing most of the short-term variance in total ozone.

\section{Summary and conclusions}

Monthly, seasonal and annual values of the total column ozone amount have been analyzed at each station of KSA. It is found that, ozone variation is function of the latitudes where the higher values of ozone occur at the northern stations, it decrease gradually from north to south. The range between the monthly values of the northern stations (60 DU) is greater than those in the southern stations (40 DU). A relatively large minimum value of ozone at all stations occur at the year 1993, this minimum follows the June 15, 1991 eruption of Mt. Pinatubo and is caused mainly by the chemical and/or dynamical effects of this aerosol injection event.

The analysis of the average monthly values (1979-2006) of ozone for each month of the year for the KSA stations indicate that the values of ozone start to increase gradually from november to reach its maximum at march then it decrease gradually to reach its minimum at october. The behaviour of ozone at the middle stations is differ from those in the northern stations, where the lowest values appear at winter months and the highest values appear at spring and summer months. 
The differences between the average values of some months at southern stations and the northern stations reache to $30 \mathrm{DU}$. The analysis of the seasonal and annual time series of KSA stations illustrate that the annaul and seasonal values of ozone decreases gradually from northern station to southern station, which means that it decreases with decreasing latitudes. There is no persistance in the season of higher ozone values, where the season of higher values is differ with different latitudes. It is found that, the arrange of the higher seasonal values of ozone for the stations that lie between $31.68-30.90^{\circ} \mathrm{N}$ is Spring, Winter, Summer and Autumn, while at the stations that lie between $29.78-27.90^{\circ} \mathrm{N}$ is Spring, Summer, Winter and Autumn. Also for the stations that lie between $26.30-24.140^{\circ} \mathrm{N}$ is Spring, Summer, Autumn and winter, while for the stations that lie between $21.71-16.90^{\circ} \mathrm{N}$ is Summer, spring, Autumn and winter. The variability of ozone in the low- latitude is acceptabley small at a few DU, where as it becomes unsutiably large when extending outside the tropics.

Study of the horizontal distribution of the monthly average of ozone $(1979$ - 2006) for each month of the year has been made. Its found that, because most ozone lies in the stratosphere, stratospheric column ozone and total column ozone exhibit similar seasonal cycles and latitudinal variability. The largest column amounts occurs north of $30^{\circ} \mathrm{N}$ during winter- spring months and coincide with a lowering of the tropopause. Latitudinal gradients in column ozone are very strong in winter and spring months specially north of latitude $20^{\circ} \mathrm{N}$. Latitudinal gradients in winter and spring months are $\approx 3-4$ times 
larger than in summer and autumn seasons. Despite the differences in latitudinal gradient in ozone south of $20^{\circ} \mathrm{N}$ exhibite the smalest amounts in winter- spring months. The climatological distribution of ozone throughout the months of the year reflect the effect of meteorological factors and pressure system affecting in weather and climate of our area. The strong latitudinal gradient of ozone with the increase of its quantity over the north of KSA in winter and spring is due to midlatitude traveling depressions from west to east that affect the weather in this period.

\section{References}

Aesawy, A.M., Mayhoub, A.B. and Sharobim, W.M. 1994. 'Seasonal variation of photochemical and dynamical components of ozone in subtropical regions', Theor. Appl. Climatol., 49, 241-247.

Dobson, G. M. B. and Harrison, D. N. 1926: Measurements of the amount of ozone in the earth's atmosphere and its relation to other geophysical conditions, Proc. Royal Society London A, 110, 660-693.

Dobson, G. M. B., 1930: Measurements of the amount of ozone in the Earth's atmosphere and its relations to other geophysical conditions, Part IV, Proc. Roy. Soc., A129, 411433.

Dobson, G. M. B., Harrison, D. N., and Lawrence, J.1929: Measurements of the amount of ozone in the earth's atmosphere and its relation to other geophysical conditions, iii, Proc. Royal Society London A, 122, 456-486.

Dobson, G.M.B., A.W. Brewer and B.M. Cwilong, 1946: Meterorolgy of the lower atmosphere. Proc. Roy. Soc. London, A 185, 144-175.

Hadjinicolaou, P., J.A. Pyle, M.P. Chipperfield, and J.A. Kettleborough, 1997: Effect of interannual meteorological variability on midlatitude O3, Geophys. Res.Lett., 24, 2993-2996.

Holton, J.R., P.H. Haynes, M.E. McIntyre, A.R. Douglass, R.B. Rood, and L.Pfister, 1995:Stratosphere-Troposphere exchange,Rev. Geophys.,33,403-439. 
Hudson, R. D., A. D. Frolov, M. F. Andrade, and M. B. Follette, 2003: The total ozone field separated into meteorological regimes. Part I: Defining the regimes. J. Atmos. Sci., 60, 1669-1677.

James, N. I., 1994: Introduction to Circulating Atmospheres. Cambridge University Press. Cambridge, U .K. 422p.

Kiyohiko Nakamura, 1994: Competitive parallel processing of millisecond scale in the neocortical circuitry. Computation in Neurons and Neural Systems: Proc. of Second Annual Computation and Neural Systems Meeting, F. H. Eeckman(ed.), Kluwer Academic Publishers: Norwell, 313-319.

Kowalok, M. E.,1993: Common Threads - Research Lessons from Acid Rain, Ozone Depletion, and Global Warming. Environment 35(6), 13-38.

Peters, D., and D. W. Waugh, 1996: Influence of barotropic shear on the poleward advection of upper-tropospheric air, J. Atmos. Sci., 53, 3013- 3031.

Reed, R.J. 1950: 'The role of vertical motions in ozone-weather relationships', J. Meteorol., 7, 263-267.

Reid, S.J., A.F. Tuck, and G. Kiladis,2000: On the changing abundance of ozone minima at northern midlatitudes,J. Geophys. Res., 105, 12169-12180, 2000.

Rozanov, V. V., Buchwitz, M., Eichmann, K. U., de Beek, R., and Burrows, J. P., 2002: SCIATRAN - A new radiative transfer model for geophysical applications in the 240-2400 nm spectral region: The pseudo-spherical version, presented at COSPAR 2000, Adv. Space Res., 29(11), 1831-1835.

Shen, L. T., Wooldridge, J. P., and J. M., Molina, 1995: Stratospheric pollution and ozone depletion. In: Singh, B. H. Composition, Chemistry, and Climate of the Atmosphere. Van Nostrand Reinhold. New York. 394 -442.

Stenchikov, G., A. Robock, V. Ramaswamy, M. D. Schwarzkopf, K. Hamilton, and S. Ramachandran, 2002: Arctic Oscillation response to the 1991 Mount Pinatubo eruption: Effects of volcanic aerosols and ozone depletion, J. Geophys. Res., 107 (D24), 4803.

Waugh, D.W., L.M. Polvani, and R.A. Plumb, 2000: Nonlinear barotropic response to a localized topographic forcing: formation of a 'tropical surface ozone' and its effect on interhemispheric propagation, J. Atmos. Sci. 51, 1401-1416. 


\section{تحليل الأوزون فوق المملكة العربية السعودية}

\section{عبا الرحمن خلف الخلف}

كلية الأرصاد والبيئة وزراعة المناطق الجافة - جامعة الملك عبد العزبيز

$$
\text { جدة - المدلكة العربية السعودية }
$$

المستخلص. نم تحليل بيانات الأوزون الكلية شهريا وفصليا وسنويا لكل

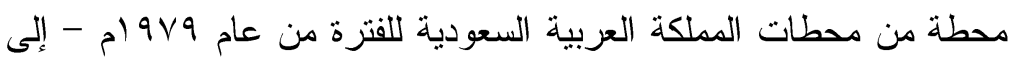

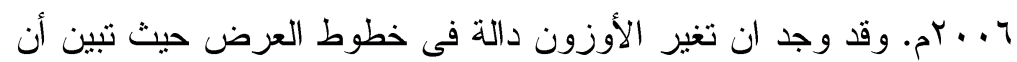

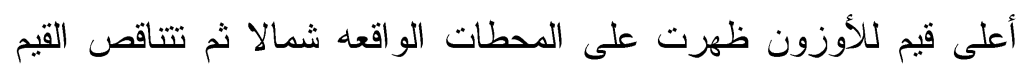

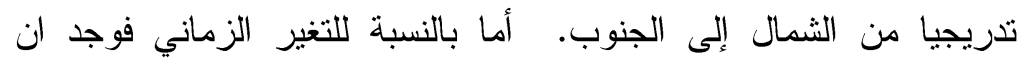

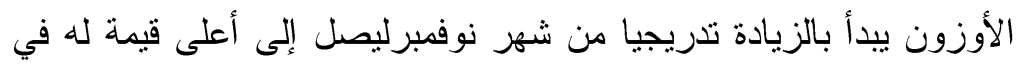

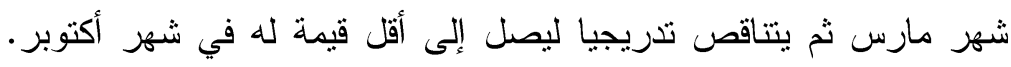

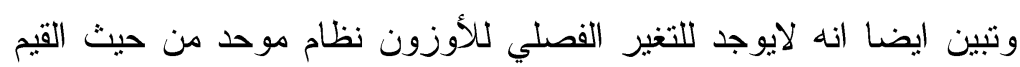

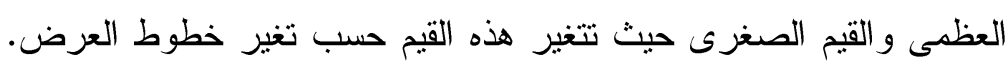

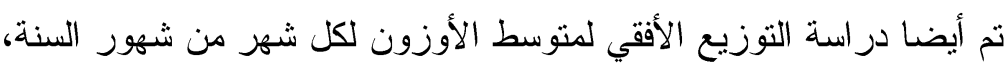

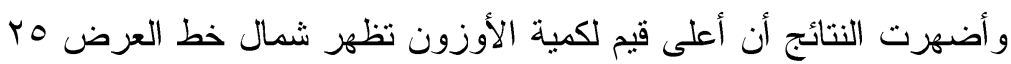

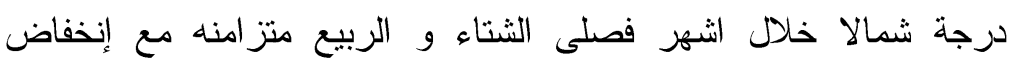

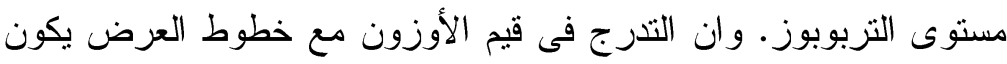

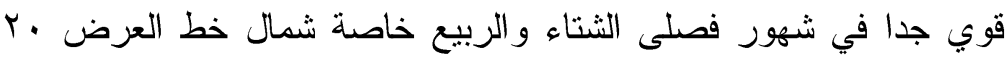

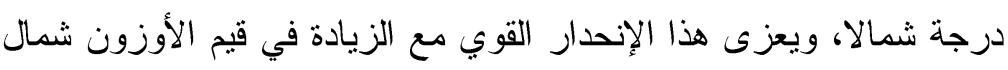

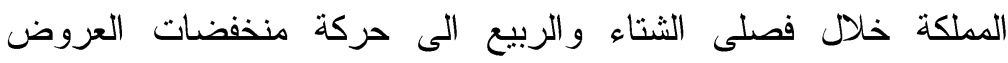
الوسطى السيارة من الغرب إلى الثرق و التي تؤثر على الطقس في هذه هذه

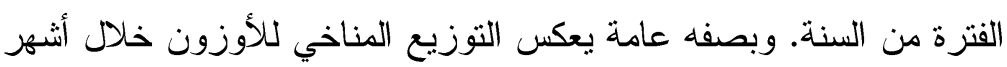

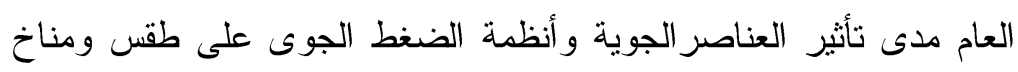

